\title{
Structure and Diversity of Sal Forests in Government and Community Management Systems in Kumaun Region of Central Himalaya
}

\author{
BHAWANA KAPKOTI ${ }^{\star 1}$, BHAWNA ADHIKARI ${ }^{1}$, NEELU LODHIYAL ${ }^{1}$ and L. S. LODHIYAL ${ }^{2}$ \\ ${ }^{1}$ Department of Botany, D.S.B. Campus, \\ ${ }^{2}$ Department of Forestry \& Environmental Science, \\ D.S.B. Campus, Kumaun University, Nainital-263002, UK. \\ http://dx.doi.org/10.12944/CWE.11.1.16
}

(Received: February 29, 2016; Accepted: March 18, 2016)

\begin{abstract}
The present study deals with structure, diversity and regeneration of Sal (Shorea robusta Gaertn.) forests in Kumaun region of Central Himalaya. Two forest types were investigated i.e. Sal dominant forest and Sal teak (Tectona grandis Linn.) mixed forest in Kumaun Himalaya. Tree, sapling and seedling density was 650-911, 36-1303 and 400-6656 ind.ha-1, respectively. Sal showed reverse $\mathrm{J}$-shaped curve representing good regeneration and $T$. grandis showed reverse bell shaped indicating fair regeneration in community management system while Sal showed poor regeneration in the government management forest. Sal showed comparatively good regeneration in Sal mixed in community managed forest while poor regeneration in Sal dominant government management system. Over exploitation of Sal species for basic needs of people consequently impart the negative impact on regeneration of forest. Thus it is suggested that in mixed forests with higher number of species reduces the pressure on individual species as brought by local people so that forest should be managed and conserved sustainably.
\end{abstract}

Key words: Shorea robusta; Tectona grandis; density; species diversity; regeneration; Van panchayat.

\section{INTRODUCTION}

Forests of Himalaya play significant role for sustainable development of the region as they not only provide timber and resin to industries but also fulfills the basic needs of villagers such as fuel, small timber, fodder, and other minor products residing nearby areas. Forest area and forest cover accounted for about 65 and 46 percent in the Uttarakhand. In Kumaun region, forest cover is 40.3 percent of the state's forest cover. The maximum forests are being managed by foresters while a small area $(20 \%)$ is under the management control of village community commonly known as Van Panchayat forests. The dependence of hill people for their basic needs lies only in community managed (Van Panchayat) forests because of strict rules implemented by the government forest department. Therefore in community managed forests the resource extraction pressure are growing regularly, consequently impacting the existence of such forests as the forest sites contain very small number of usable plant species. In our study sites, Sal is one of the dominant forest communities in Shiwalik of Kumaun region in Uttarakhand. This region is also mostly populated and having different development activities therefore the forests in the area are suffering from human and animal's pressure. Since last five decades, such growing anthropogenic pressure on forests and expansion of infrastructure has led to over exploitation of flora and fauna. Conservation of biological resources under community based conservation system is a key tool to lessen the depletion of biodiversity. In many part of Central Himalayan region and elsewhere due to deforestation and forest degradation showed that the 
diversity, species composition and regeneration of forest tree species are being changed consequently influencing the productivity and sustainability of the forest ecosystems ${ }^{1}$. The deforestation and over exploitation activities in forests not only concentrated in the lower belt but it also expanded in the upper part of Himalayan forests dominated with broad-leaved and conifer forest species. Population structure of tree species in a forest conveys its regeneration behavior, which is characterized by the presence of sufficient population of seedlings, saplings and young trees for successful regeneration ${ }^{2}$.

Forests are one of the major sources of biodiversity and it is essential for human survival and economic well being and for the ecosystem function and stability ${ }^{3}$. Economically and environmentally, the natural resources are the main source for people in Kumaun region ${ }^{4}$. The forest of tropical dry deciduous, generally dominated by Sal (Shorea robusta) natural forests ${ }^{5}$ planted forest species included teak (Tectona grandis) followed by Acacia catechu and Syzygium cumini ${ }^{6}$. Composition of the forest is diverse and varies from place to place because of varying topography such as plains; foothills and upper mountains ${ }^{7}$. On a global basis, $52 \%$ of the total forests are tropical forests having rich species diversity ${ }^{8,9,10,11}$. In the Himalayan forest, various changes are appearing in their structure, density, composition and regeneration due to biotic pressure on them such as illegal lopping and cutting of trees for fuel wood, fodder and grazing ${ }^{12}$. There are several

Table 1: Geographical locations in studied different forest types

\begin{tabular}{lccccc}
\hline Forest site & Forest type & Latitude & Longitude & $\begin{array}{c}\text { Elevation } \\
(\mathbf{m})\end{array}$ & $\begin{array}{c}\text { Management } \\
\text { regime }\end{array}$ \\
\hline Musabangar (site-I) & Sal dominant forest & $29^{\circ} 32^{\prime}$ & $79^{\circ} 24^{\prime}$ & $500-580$ & $\begin{array}{c}\text { Government } \\
\text { managed } \\
\text { Community } \\
\text { mananaged }\end{array}$ \\
\hline
\end{tabular}

Table 2: Density (ind.ha-1) of trees, saplings and seedlings in each studied forest site

\begin{tabular}{|c|c|c|c|c|c|c|c|}
\hline \multirow[t]{2}{*}{ Species } & \multirow[t]{2}{*}{ Family } & \multicolumn{3}{|c|}{$\begin{array}{c}\text { Government } \\
\text { managed forest }\end{array}$} & \multicolumn{3}{|c|}{$\begin{array}{c}\text { Community } \\
\text { managed forest }\end{array}$} \\
\hline & & Tree & Sapling & Seedling & Tree & Sapling & Seedling \\
\hline Shorea robusta & Dipterocarpaceae & 613 & 3 & - & 570 & 1060 & 3290 \\
\hline Tectona grandis & Verbenaceae & - & - & - & 217 & 100 & 483 \\
\hline Mallotus philippensis & Euphorbiaceae & 37 & 30 & 350 & 17 & 20 & 863 \\
\hline Cassia fistula & Caesalpiniaceae & - & - & 20 & 27 & 10 & 180 \\
\hline Syzygium cumini & Myrtaceae & - & - & - & 37 & 20 & 360 \\
\hline Holarrhena pubescens & Apocynaceae & - & - & - & 10 & 37 & 673 \\
\hline Dalbergia lanceolaria & Fabaceae & - & - & - & 7 & 7 & 33 \\
\hline Aegle marmelos & Rutaceae & - & - & - & 7 & 3 & 3 \\
\hline Randia dumetorum & Rubiaceae & - & - & 7 & 13 & 37 & 673 \\
\hline Mangifera indica & Anacardiaceae & - & - & - & 3 & - & 7 \\
\hline Ficus hispida & Moraceae & - & - & - & 3 & 3 & 10 \\
\hline Holoptelea integrifolia & Ulmaceae & - & 3 & 23 & - & 3 & 37 \\
\hline Grewia asiatica & Tiliaceae & - & - & - & - & - & 10 \\
\hline Haldina cordifolia & Rubiaceae & - & - & - & - & 3 & 17 \\
\hline Schleichera oleosa & Sapindaceae & - & - & - & - & - & 17 \\
\hline Total & & 650 & 36 & 400 & 911 & 1303 & 6656 \\
\hline
\end{tabular}


methods to study the regeneration status such as a dominance diversity curve ${ }^{13}$ a density diameter curve $^{14}$ and the population structure ${ }^{2}$. The objectives of present study were to assess the tree structure and regeneration of Sal forests in two different management systems in foot hills of Kumaun region of Central Himalaya.

Table 3: Species diversity $\left(\mathrm{H}^{\prime}\right)$ and concentration of dominance $(\mathrm{Cd})$ of tree species in each forest site

\begin{tabular}{lcccc}
\hline Tree layer & $\begin{array}{c}\text { Government managed forest } \\
\text { Cd }\end{array}$ & \multicolumn{2}{c}{$\begin{array}{c}\text { Community managed forest } \\
\text { H' }\end{array}$} & \\
\hline Tree & 0.313 & 0.894 & 1.681 & 0.452 \\
Sapling & 0.871 & 0.674 & 1.182 & 0.670 \\
Seedling & 0.722 & 0.772 & 2.363 & 0.291 \\
\hline
\end{tabular}
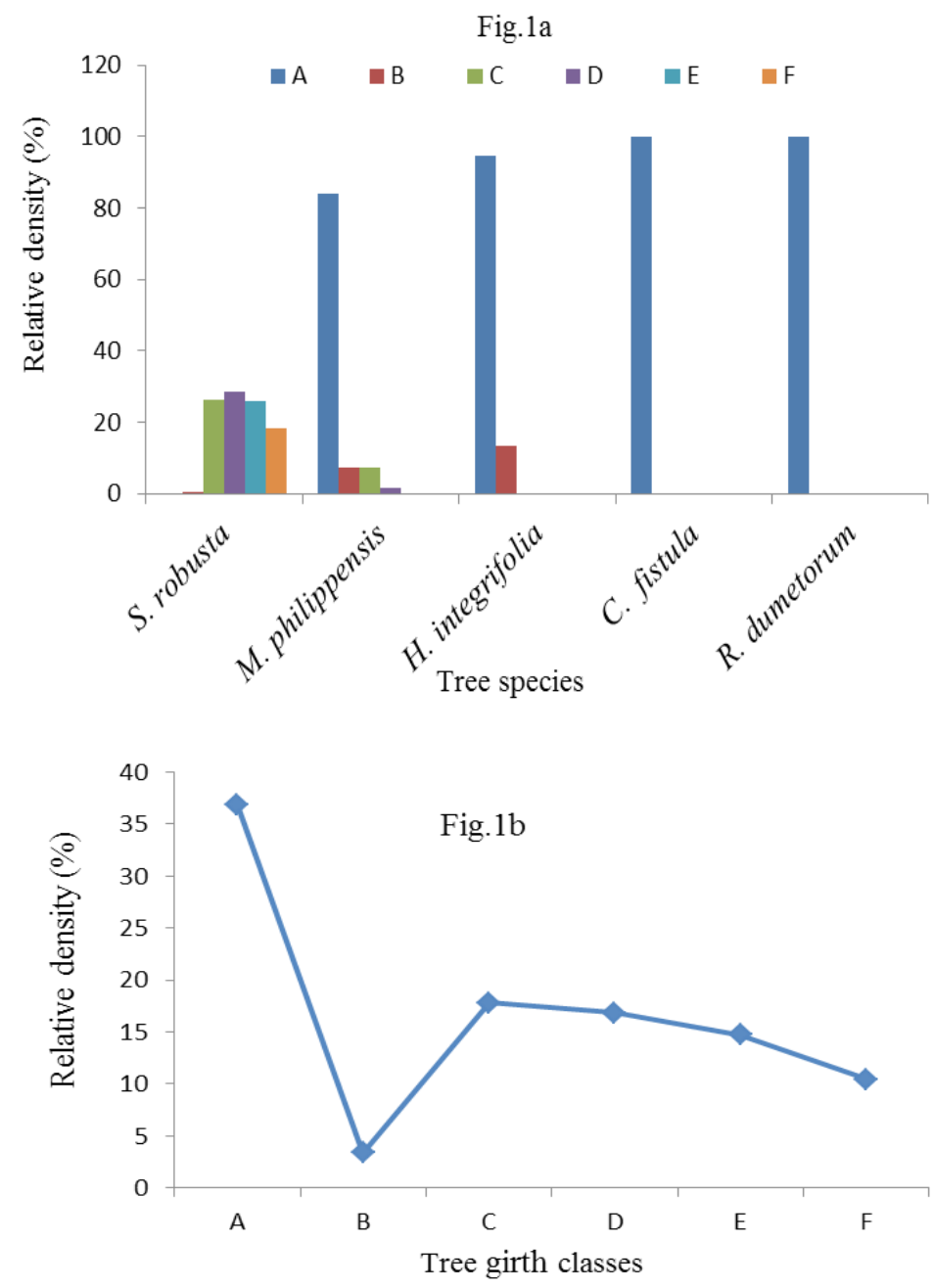

Fig. 1: Population structure Fig. 1a and regeneration status of tree species (fig.1b) in government managed forest site. Different size girth classes i.e. $A=$ seedling $0-10.0 \mathrm{~cm}, B=$ sapling 10.1 $30.0 \mathrm{~cm}, \mathrm{C}=30.1-60 \mathrm{~cm}, \mathrm{D}=60.1-90.0 \mathrm{~cm}, \mathrm{E}=90.1-120 \mathrm{~cm}$ and $\mathrm{F}=>120.0 \mathrm{~cm}$ 


\section{MATERIALS AND METHODS}

\section{Description of study sites}

The present study has been carried out in Kotabagh Block forest of Nainital District in central Himalaya region of Uttarakhand, India. At the study site, two forest types i.e. Sal dominant and Sal mixed teak forest (Table 1).

\section{Sampling and data analysis}

Vegetation analysis was done by using quadrat method ${ }^{15,14}$. The size of quadrat used for tree layer analysis was $10 \times 10 \mathrm{~m}$. The sample size was one hectare forest, which was divided into four sub- sample plots of size $50 \times 50\left(2500 \mathrm{~m}^{2}\right)$. In each sub-sample plot, tree species were measured and categorized into different girth classes i.e. $<10 \mathrm{~cm}$ for
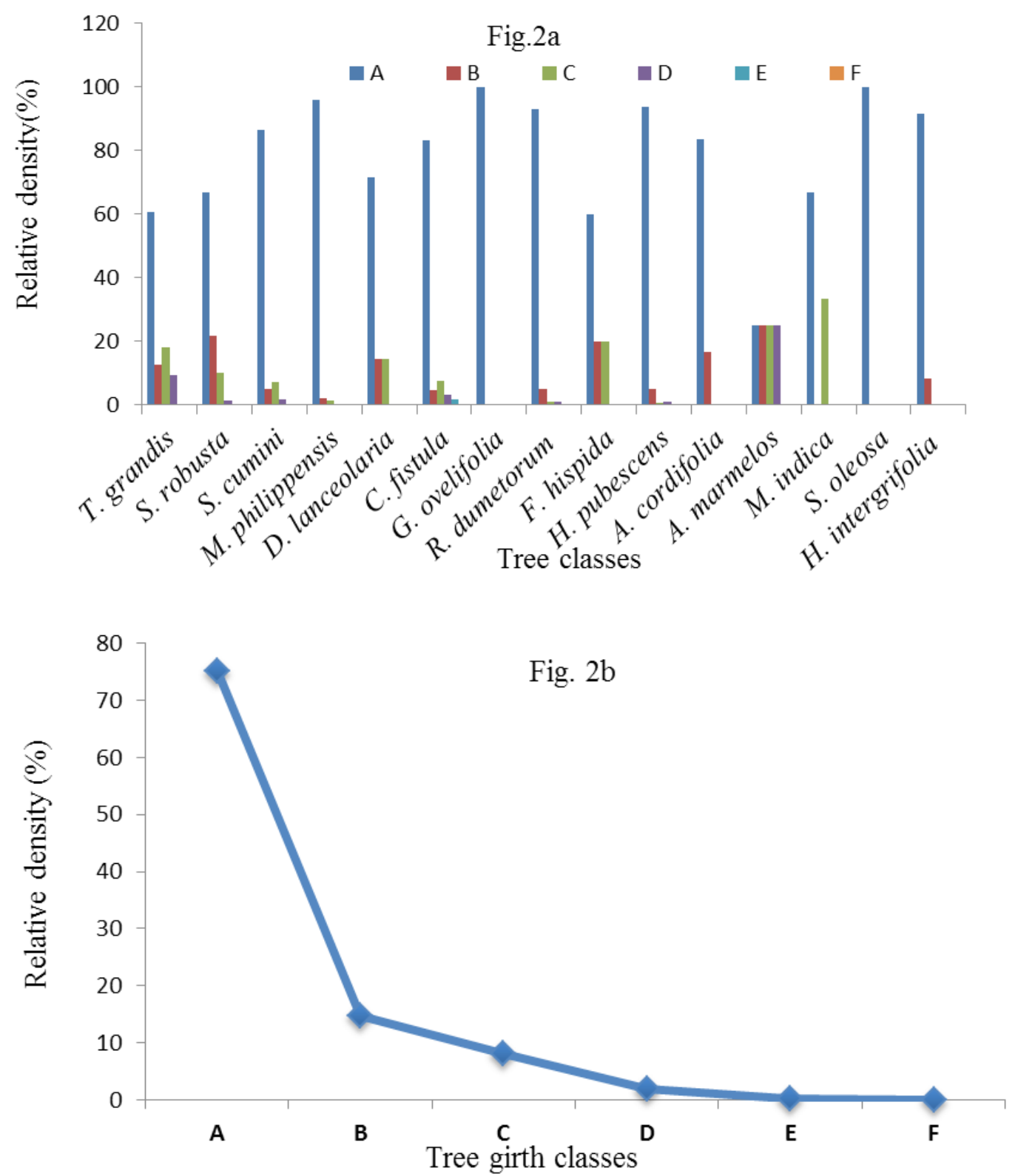

Fig. 2: Population structure fig.2a and regeneration of tree species fig.2b in community managed forest. Different size tree girth classes i.e. $A=$ seedling $0-10.0 \mathrm{~cm}, B=$ sapling $10.1-30.0 \mathrm{~cm}, C=30.1-$ $60.0 \mathrm{~cm}, D=60.1-90.0 \mathrm{~cm}, E=90.1-120.0 \mathrm{~cm}$ and $F=120.1 \mathrm{~cm}<$ 
trees. The girth of seedling and sapling was taken at 15 and $50 \mathrm{~cm}$ from ground level respectively. The tree girth was measured at breast height i.e. $1.37 \mathrm{~m}$ from ground level. The regeneration of tree species in each forest was assessed as discussed and followed Shanker ${ }^{16}$. Tree species diversity of forest was determined by using Shannon-Weiner information index ${ }^{17}$.

\section{RESULTS}

\section{Tree vegetation analysis}

Total 15 tree species were reported in studied forest sites. These numbers of species in each tree category consisted of viz., Shorea robusta Gaertn., Tectona grandis Linn., Cassia fistula Linn., Mallotus philippensis (Lam.)MuellArg., Syzygium cumini (L.) Skeels., Ficus hispida Linn, Holarrhena pubescens (Buch.- Ham.) wall, Schleichera oleosa Lour., Randia dumetorum Retz., Holoptelea intergrifolia Roxb., Haldina cordifolia (Roxb.) Ridsdale, Aegle marmelos L., Dalbergia lanceolaria L., Grewia asiatica L., and Mangifera indica L. reported in both forest sites.

Total density of tree, sapling and seedling were 650, 36 and 400 ind.ha ${ }^{-1}$ in government managed forest and 911, 1303 and 6656 ind.ha $^{-1}$ for community managed (van panchayat) forest, respectively (Table 2). The species diversity for trees, saplings and seedlings was $0.313,0.871$ and 0.722 while concentration of dominance was $0.894,0.674$ and 0.772 respectively, in government managed forest. The species diversity was $1.681,1.182$ and 2.363 and concentration of dominance was 0.452 , 0.670 and 0.291 in community managed forest, respectively (Table 3 ).

\section{Regeneration of tree species}

The relative proportion of seedlings, saplings, and trees of different size classes to the total density of tree species at each forest site were calculated to develop the population structure. In government managed forest tree species showed fair regeneration which was in order: Seedling $>$ Sapling $<$ Tree. But the Sal tree showed poor regeneration while M. philippensis showed fair regeneration. The other tree species such as $H$. integrifolia, $C$. fistula and $R$. dumetorum were also reported in the studied forest (Fig.1). Sal was dominant and teak was co-

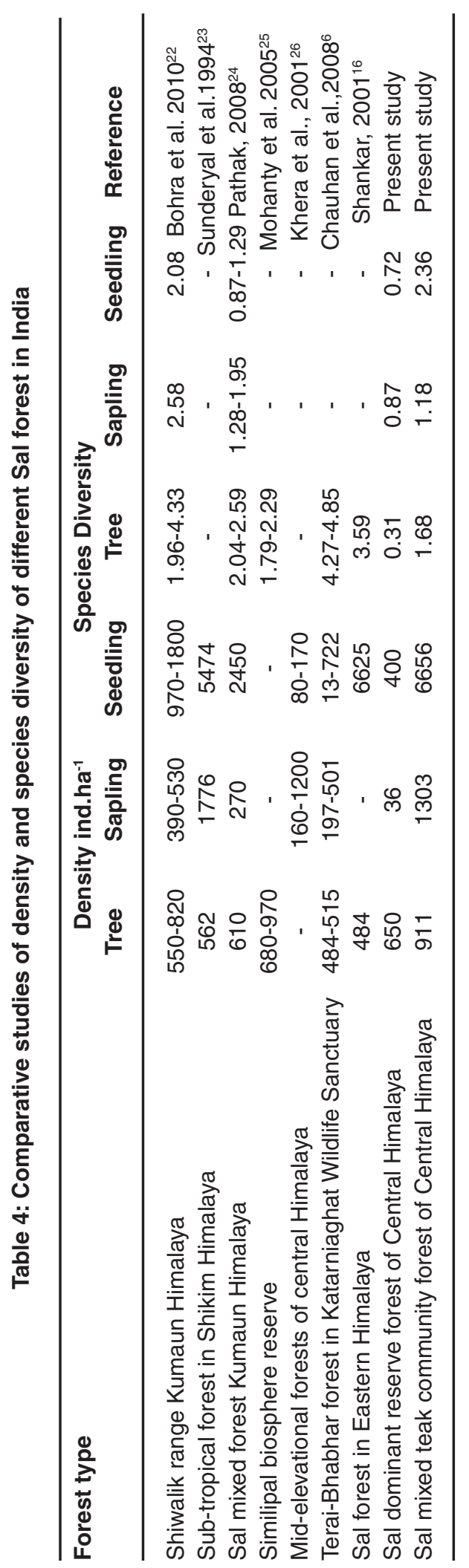


dominant tree species in community managed forest. Where Sal showed reverse J-shape curve indicating good regeneration (seedling >sapling >tree) and teak showed fair regeneration while the other tree species also have showed fair regeneration (Fig.2).

\section{DISCUSSION}

In the Himalayan region, forest tree species composition and structure vary from lower to higher elevations due to varying soil and climatic conditions. Apart from these, the management and usufructs extraction methods used by foresters and village community people. In this study, the species diversity and regeneration results of government managed forests were not found satisfactory compared to community management forests because of large area of forests as well as higher density of tree species. However, diversity of species in each forest management system was on the lower side than forests studied in other parts of the region and elsewhere (Table 4). It showed that forests in both management systems declined their species diversity that may be due to poor inputs of management and unsustainable use of usufructs from the forests. It is stated that forest dominated by individual one as in case of government management system, the tree density was on lower side than community management system having more number of species and density. So it is concluded that the forest that were managed by community having more density and diversity compared to the forest managed by government.
The regeneration and density of teak was similar to those have been reported for the same species by Carnevale and Monlagnii (2002) and Kaewkrom et al., (2005) ${ }^{18,19}$. They also reported that the regeneration of teak tree species with regard to density was higher in mixed forest plantation than pure forest plantation. The seedlings, saplings and trees of a plant species exhibit the population dynamic which is used to decide their regeneration status $^{20}$. The recruitment of seedlings was higher in Sal forests but its seedlings were unable to reach adult stage because of disturbances brought by frequent fire incidence, erosion of soil and water, uncontrolled grazing by nearby animals, cuttings of under canopy plant species by villagers for their domestic cattle. In case of teak, seedlings were higher but they are unable to reach sapling stage because of uprooting of seedlings for nursery use by the foresters and villagers. Besides this, the use of saplings for fuel and agriculture purposes by local people. According to Good and Good (1972) ${ }^{21}$ the soil nutrient, water and sunlight conditions may be the major factors for successful regeneration of tree species. Thus it is concluded that in mixed forests with more number of tree species possibly reduces the pressure on individual species which brought by local people for their use, therefore such forest comparatively received better time for their growth and development.

\section{ACKNOWLEDGMENT}

The first author is thankful to the University Grant Commission, New Delhi for providing the financial assistance under UGC-SAP (BSR) research fellowship.

\section{REFERENCES}

1. Lodhiyal, L.S., Lodhiyal, N., and Kapkoti, B., Structure and diversity of tree species in natural forests of Kumaun Himalaya in Uttarakhand. Journal of Plant Development Sciences, 5(2): 97-105 (2013)

2. Saxena, A.K., and Singh, J.S., Tree population structure of certain Himalayan forest associations and implications concerning their future composition. Vegetatio, 58: 61-69 (1984)
3. Singh, J.S., The biodiversity crisis: a multifaceted review. Current Science, 82: 638-647 (2002)

4. Ram, J., Kumar, A., and Bhatt, J., Plant diversity in six forest types of Uttaranchal, Central Himalaya, India. Current Science, 86 : 975-978 (2004)

5. Champion, H.G., and Seth, S.K., Revised Survey of the Forest Types of India. Publication Division, Govt. of India, New Delhi ( 1968) 
6. Chauhan, D.S., Dhanai, C.S., Singh, B., Chauhan, S., Todaria, N.P., and Khalid, M.A., Regeneration and tree diversity in natural and planted forests in a Terai- Bhabhar forest in Katarniaghat Wildlife Sanctuary, India, Tropical Ecology, 49(1): 53-67 (2008)

7. Singh, J.S., Sustainable development of the Indian Himalayan region: Linking ecological and economic concerns. Current science, 90(6): 784-788 (2006)

8. Pitchairamu, C., Muthuchelian, K., and Siva, N., Floristic inventory and quantitative vegetation analysis of tropical dry deciduous forest in Piranmalai forest, Eastern Ghats, Tamilnadu, India. Ethnobotanical Leaflets, 12: 204-216 (2008)

9. Sagar, R., and Singh, J.S., Structure, diversity, and regeneration of tropical dry deciduous forest of northern India. Biodiversity and Conservation, 14: 935-959 (2005)

10. Kadavvul, K. and Parthasarathy, N., Plant biodiversity and conservation of tropical semi-evergreen forests in the Shervarayan hills of Eastern Ghats, India. Biodiversity and Conservation, 8: 421-439 (1999)

11. Kumar, Y., Floristic studies on Balphakram wildlife sanctuary in Meghalaya-5: rare, endemic or threatened flora. Journal of Meghalaya Science Society, 11: 33-48 (1989)

12. Kumar, M., Sharma, C.M., and Rajwar, G.S., A Study on Community Structure and Diversity of a Sub Tropical forest of Garhwal Himalaya. Indian Foresters, 130(2): 207-214 (2004)

13. Whittaker, R.H., Evolution and measurement of species diversity. Taxon, 21: 213-251 (1975)

14. Saxena, A.K., and Singh, J.S., Quantitative profile structure of certain forest in the Kumaun Himalayan: Proceeding of the Indian Academy of Sciences, 91: 529-49 (1982)

15. Misra, R., Ecology Work Book. Oxford and IBH Publishing Calcutta (1968)

16. Shankar, U., A case study of high tree diversity in a Sal (Shorea robusta)-Dominated lowland forest of Eastern Himalaya: Floristic composition, regeneration and conservation.
Current Science, 81: 776-786 (2001)

17. Shannon, C., and Wiener, W., The mathematical Theory of communication (Urban: University of Illinois Press) (1963)

18. Carnevale, N.J., and Montagnini, F., Facililating regeneration of secondary forests with the use of mixed and pure plantations of indigenous tree species. Forest Ecology and Management, 163: 217-227 (2002)

19. Kaewkrom, P., Gajaseni, J., Jordan, and C.F., Gajaseni, N., Floristic regeneration in five types of teak plantations in Thailand. Forest Ecology and Management, 210: 351-361 (2005)

20. Teketay, D., Seedling populations and regeneration of woody species in dry Afromontane forests of Ethiopia. Forest Ecology and Management, 98: 149-165 (1997)

21. Good, N.F., and Good, R.E., Population dynamics of tree seedlings and saplings in mature Eastern hardwood forest. Bulletin of Torrey Botanical Club, 99: 172-178 (1972)

22. Bohra, C.S., Lodhiyal, L.S., and Lodhiyal, N., Forest stands structure of Shiwalik region of Nainital district along an altitudinal gradient in India Central Himalaya. New York Science Journal, 3(12): 82-90 (2010)

23. Sundriyal, R.C., Sharma, E., Rai, L.K., and Rai, S.C., Tree structure, regeneration and wood biomass removal in a Sub- Tropical forest of Mamlay watershed in the Sikkim Himalaya. Vegetatio, 113: 53-63 (1994)

24. Pathak, G.C., Vegetation analysis and productivity of Shorea robusta Gaertn. F. and Pinus roxburghii Sarg. In Kumaun Himalaya. Ph. D. thesis, Kumaun Universty. (2008)

25. Mohanty, R.C., Mishra. R.K., Bal, S., and Upadhyay, V.P., Plant diversity assessment of Shorea robusta dominated forest stands of Similipal biosphere reserve. Journal of Indian Botanical Society, 84: 21-29 (2005)

26. Khera, N., Kumar, A., Ram, J., and Tewari, A., Plant biodiversity assessment in relation to disturbances in mid-elevational forest of Central Himalaya, India. Tropical Ecology, 42(1): 83-95 (2001). 